\title{
Inclusive, Responsive, Democratic Local Government Institution and Active Citizens
}

\begin{abstract}
Anita Marianata ${ }^{*}$
Abstract

Reform in decentralization and village democratization can be seen in the involvement of villagers in the policy-making process, both in the economic, political and rural development fields. In the community planning process there is widespread (participatory) community involvement. The involvement of citizens in village development is one part of the development goals. Equality, justice, non-violence, tolerance, inclusiveness, transparency, accountability and responsiveness are principles that must be put forward in the village development planning process. The involvement of citizens in village development planning and budgeting aims to ensure and identify what should be the development priorities, policies, programs and activities that require budget or resources. By using a descriptive qualitative approach, this research is expected to be able to understand more deeply about inclusive and responsive democracy carried out by village government institutions and the involvement of villagers' participation. This is one of the first steps that should be taken by the village government in building democracy at the village level.
\end{abstract}

\section{Keywords:}

democracy; inclusive; responsive; citizen participation

\section{Introduction}

Indonesia as an independent archipelagic country in 1945 also had the goal of the State to be achieved. This goal has been enshrined in the constitution, especially at the opening of the constitution in the fourth paragraph, namely (i) protecting the entire Indonesian nation and all the bloodshed of the State of Indonesia; (ii) promote general welfare; (iii) educate the life of the nation and (iv) participate in carrying out world order. All of these goals are metabolized through legal products issued by the government itself, which encourages the welfare of the nation. In the constitution, the Indonesian founding father has agreed that democracy is the foundation of the life of the nation which is correlated by the Indonesian culture itself which is very noble.
Village renewal does not only cover renewal of the agrarian field, but also promotes renewal of decentralization and democratization at the village level. These things can be known by the existence of Law No. 6/2014 concerning Village Governance, the whole system of village governance changes drastically. The village has the authority to manage finances independently. If the capacity of the village apparatus is not improved, then the stakes will be many corrupt practices involving the village apparatus. Dramatic development of governance and a significant leap.

Based on a study conducted by Silver from Brown University (2017), the excluded group found obstacles in obtaining legal identity (KTP, Birth Certificate, Jamkesmas, etc.), participating in the economy, accessing

\footnotetext{
- Public Administration, Faculty of Social Science and Political Science, University of Bengkulu

Email: anitamarianata@gmail.com
} 
basic health services, accessing basic education services, interacting with the community and the opportunity to play a role in society. Silver emphasized in the results of his study that the groups above were generally the poorest groups in society. Poor economically, politically and socially.

This exclusion occurs continuously between generations, so that the parties who exclude are often unaware and consider as reasonable. Inequality and marginalization of gender, disability, ethnicity, or origin are influenced, and affect both private and public life. Governments and basic service providers have responsibilities and opportunities to improve equality and uphold the rights of vulnerable communities. Inequality is very closely related to social exclusion. Social exclusion can drive the poor into deeper poverty, and make it difficult for them to get out of poverty. Those who are excluded based on gender, race, social status, ethnicity, religion and sexual orientation are often faced with various forms of deprivation or loss of rights and opportunities that result in lower social status and income levels, more limited access to employment opportunities and basic services, and lack of voice or involvement in decision making.

Village development in Law No. 6/2014 concerning Villages (Village Law) starts from the village planning and development process. Village Fund planning and budgeting is the entrance to equitable and prosperous village development as mandated in the Village Law. In the community planning process there is widespread (participatory) community involvement. Participatory planning contained in the Village Law must be translated as a budgeting that is carried out in an open, professional, proportional and accountable manner. Pro-poor planning and budgeting and response to gender issues. Villages must be able and provide space for the community to practice the principles of democratic governance and good governance.
Implicitly the Village Law opposes parochial villages and corporatist villages, to encourage the growth of inclusive villages. The concept of inclusiveness literally means for all, or for example it can be formulated into a village for all, or it could be that a village is lived by all and the village supports all. This is a literal meaning. But conceptually, inclusively or inclusive began to be developed by democratic theories, especially those titled inclusive democracy. Inclusive democracy is basically an alternative to ordinary democracy or formal democracy which has created a gap for minorities and marginalized who are powerless because of the tyranny of the majority or the oligarchic elite (Dryzek, 1996, p. 8). Therefore, inclusive democracy promotes the spirit of democracy for everyone, not just for the majority.

Equality, justice, non-violence, tolerance, inclusiveness, transparency, accountability and responsiveness are principles that must be put forward in the village development planning process. The ability of the village to accommodate local values is very important and absolutely necessary. The involvement of citizens in village development planning and budgeting aims to ensure and identify what should be the development priorities, policies, programs and activities that require budget allocation or resources. Participatory planning and budgeting provides opportunities for citizens to participate in the allocation of resources for the implementation of priority policies. In practice, the application of a participatory approach needs to ensure that there are alignments for the poor, women, children, people with disabilities and environmental sustainability. This is very important to ensure that the aspirations of marginal citizens are accommodated through their involvement. In addition, it will help the village government to ensure that efforts to fulfill the basic rights of villagers in realizing good public services have been fulfilled. 
Based on this, the researchers want to know and be interested in understanding more deeply about an inclusive and responsive democracy carried out by village government institutions and involving the participation of villagers. This is one of the first steps that should be taken by the village government in building democracy at the village level, and also in line with the goals of the United Nation Development Programme (UNDP) and is also one of the goals of the 17 SDGs (Sustainable Development Goals) goals.

\section{Literature Review}

\section{Inclusive Democracy}

The term democracy comes from Ancient Greece which was expressed in Ancient Athens in the 5th century BC. The country is usually considered as an early example of a system that deals with modern democratic law. However, the meaning of this term has changed over time, and modern definitions have evolved since the 18th century, along with the development of democratic systems in many countries. The word democracy comes from the word "demos" (people) and "kratos" (government), so that it can be interpreted as a people's government, or more we know as a government of the people, by the people and for the people. The concept of democracy has become a separate keyword in the field of political science. This is natural, because democracy is now referred to as an indicator of a country's political development (Gede, 2011, p. 14).

Democracy is a form or mechanism of a country's government system as an effort to realize people's sovereignty (citizen power) over the state to be run by the government of that country. One of the pillars of democracy is the principle of Trias Politica which divides the three political powers of the state into executive, judicial, and legislative. To be realized in three types of state institutions that are independent of each other and are ranked in parallel with each other. The alignment and independence of these three types of state institutions is needed so that these three state institutions can supervise and control each other based on the principle of checks and balances (Effendi, 2001, p. 5).

The three types of state institutions are government institutions that have the authority to realize and implement executive authority, court institutions that are authorized to hold judicial power and representative institutions of the people (DPR) that have the authority to exercise legislative power. Under this system, legislative decisions are made by the community or by representatives who are obliged to work and act according to the aspirations of the people they represent (constituents) and who elect them through the legislative election process, in addition to compliance with laws and regulations.

In addition to legislative elections, many important decisions or results, for example the election of a president of a country, are obtained through general elections. General elections are not obligatory or must not be followed by all citizens, but by some citizens who are entitled and voluntarily participate in general elections. According to Abraham Lincoln (16th US President), democracy is the government of, by and for the people (Democracy is the government of the people, by the people and for the people). The basic principles of democracy in a democratic government are (Alim, 2001, p. 8).

1. Recognition of people's participation in the government, for example through the election of people's representatives for parliament freely and confidentially; and

2. Recognition and protection of human rights.

Inclusive comes from "inclusive" English which means "included in it". In terms of means putting itself into the perspective of others/other groups in seeing the world, in other words trying to use the point of view of other people or other groups in understanding 
the problem. In its development the term was broadly used to build attitudes in religion so that gave birth to religious pluralism (all religions have the same truth) because of the background of religious conflicts. If carefully dissected, inclusive and exclusive attitudes are basically the way a person views existing differences.

Inclusive attitudes tend to look positively at differences, while exclusive attitudes tend to look negative at these differences. The impact of looking at the positive difference is to bring out the motivation/motivation to learn about the difference and look for its universal sides in order to gain the benefits that support life/its goals. A positive attitude towards difference is born because of the awareness that difference is natural, so it does not reject differences but acknowledges the potential for universal similarities.

Individual and social needs are broad in line with the times. Collaboration with other individuals or groups is a necessity. The principle of being inclusive arises because of the need to work together to achieve goals, the starting point is to look at the positive side of difference so as to encourage efforts to learn about differences and attract universal sides that may be positive and support the ideals/ mission of community development. Some efforts can be made to develop an inclusive attitude (Firmansyah, 2008, p. 13):

a. Recognizing that every person or group in the community has the potential to achieve truth, so as not to avoid excessive primordialism towards the superiority of himself and his group, each person or group also has a weakness that requires cooperation with other people or groups.

b. Recognizing the existence of universal aspects that may be positive for other people / other groups with different views (streams) of religion to support the achievement of the ideals / mission of community development. c. Growing a sportsmanship spirit in socializing and living together with other people / other groups, so that it is motivated to manage differences ethically or develop healthy competition despite having a different outlook and way of life.

d. Getting used to communicating soundly is not solely based on narrow perceptions and horse-eye glasses, but based on observation and understanding of differences.

Then community participation according to Isbandi in Bachtiar (2011, p. 30) is a participation that is carried out by the community in a process of identifying problems and potential that the community has, such as in the case of elections, making decisions about an alternative solution to deal with certain issues, conducting business - efforts to overcome problems, and also community involvement in evaluating changes.

Another understanding of community participation as stated by Seotrisno in Bachtiar (2011, p. 30) which defines community participation into two types. The first is people's participation in development, in this case the community becomes a person who supports an existing project or development plan. The level of high or low community participation in this case can be measured by the people's desire to be responsible in providing costs for development, both materially and services in carrying out the development.

The second type of definition regarding community participation is a form of strong cooperation between planners in this case the government and also the community, in contrast to the first definition which explains more about assistance to build a project in this second definition emphasizes on the preservation or development of a development that has been done or finished. The other definition put forward by Conyers in Deni (2006) regarding community participation is that community participation is a tool in getting information 
about the needs, conditions, and attitudes of the local community, because if there is no participation from the community there will be a possibility if a project development will not run smoothly.

Then Conyers in Deni (2006) also explained that people would be able to trust a development program if they were involved in the process of development starting from the beginning, because by doing so they would know more about the purpose of the development project. In addition, with the existence of community participation, can show a good democracy. In addition to the definitions above, there is another definition of community participation according to Mikkelsen in Deni (2006) which is divided into several definitions, namely:

a) Participation is a form of voluntary contribution from the community to a development project without participating in a decision making.

b) Participation is a form of community sensitization in increasing their desire to accept and also the ability to tackle a development project.

c) Participation is voluntary involvement carried out by the community in a change determined by themselves.

d) Participation is an active process, in the sense that a person or group concerned, has initiatives and uses their freedom to be involved in a development project.

\section{Responsive Concept}

The responsive principle is that the government must be responsive to the problems of society in general. The government must meet the needs of its people, not wait for the public to convey its aspirations, but the government must be proactive in studying and analyzing the needs of the community. So every element of government must have two ethics, namely individual ethics that demands the government to have the criteria of professional capability and loyalty. And social ethics that require the government to be sensitive to various public needs.

Responsiveness is the embodiment of corporate responsibility as a member of the community in complying with the law and acting in accordance with the values of society (Eamage, 2002). Here a company must be able to behave and or act as a good corporate citizen (good corporate citizenship).

\section{Methods}

This research was carried out in Durian Demang Village, Karang Tinggi Subdistrict, Bengkulu Tengah Regency, with the research period lasting 6 (six) months. The research method with the right data collection techniques needs to be formulated, to obtain an objective picture of a research (Sugiyono, 2009), so that it can explain as well as answer the research problems that have been predetermined (Arikunto, 2010). In this study researchers used the research that will be explained below.

Data collection methods in this study are intended to obtain relevant and accurate data with the issues discussed. Data collection methods are as follows (Usman, 2008):

1. Observation. Observation is a method used as one of the tools in collecting data based on direct observation of Durian Demang Village, Karang Tinggi District, Bengkulu Tengah Regency. Observing the process of democracy implementation in village government.

2. Interview. The interview is a direct dialogue to obtain information from selected informants in gathering information relevant to the research that will be held in Durian Demang Village, Karang Tinggi District, Bengkulu Tengah Regency. And the informan is people from Durian Demang Village.

3. Focused Group Discussion (FGD). The FGD was conducted by involving local community leaders, village officials, 
community members and administrators of organizations in the village of Durian Demang Village.

\section{Discussion}

Indigenous people who are also racially termed as indigenous have long been discriminated against, at least since the introduction of racial politics in the Dutch colonial period. At that time, the colonial government segregated the population in groups based on its racial affiliation, which consisted of Europeans, foreigners (foreign orientals) and Indigenous people. This population classification is a form of racial political implementation that builds social stratification based on race.

After independence, Indigenous victories over Europe did not necessarily change the formation of colonial power as a whole. Henley \& Davidson (2010, p.7) mentions that the revival of sentiment - post-independence tribalistic sentiments are also destructive and cannot be separated from Indonesia's ambivalent history.

On the one hand, the national journey tries to eliminate and want to break the history of the traumatic experience of the colonial era while building collective pledges for the realization of equality, social justice and democracy. But on the other hand, these normative ideals did not materialize. Instead of realizing the imagination together as a nation with civilization, the reality of state travel is precisely the replica of the power of the colonial era.

In this context, the post-colonialism approach is relevant to describing the sustainability of colonial politics in third world countries, including Indonesia. In general, the impact of social exclusion of indigenous peoples is structural impoverishment. The main reason is that the Indonesian legal framework has not completely cut the impoverishment cycle of the indigenous people. In the context of indigenous communities, the legal scheme for recognizing the rights of indigenous peoples is still conditional.

Conditional recognition of indigenous peoples' rights is further complicated by the recognition procedure, which is submitted to the political process in the region through local law products, so that with the weak capacity of indigenous peoples, recognition is still difficult to access.

The village is a social institution as well as a state institution that is closest to indigenous peoples. The Village Law explicitly mentions a combination of social and state institutions that are autonomous (local self-governance). As a leading formal institution, villages have a strategic role in the implementation of development, basic services, while creating conditions for local democracy, participation of social groups and social inclusion, especially in terms of social acceptance and recognition of indigenous identity at the site level.

Using village institutions in the strategy of encouraging social inclusion as an effort to reduce social exclusion of indigenous peoples should first understand the type of relations between indigenous peoples and village institutions. The relationship of village institutions with indigenous peoples has at least two types, namely, First, a homogeneous Village Type with a relatively uniform (homogeneous) tendency of society. This type allows indigenous peoples to have the maximum quality of participation to integrate customary rights in the village as state institutions. For example Nagari in West Sumatra. Second, heterogeneous village types with the tendency of the minority and inferior position of indigenous peoples from other community groups. For example the Suku Anak Dalam community in Jambi.

The above types of villages are related to the strategy of building social inclusion of indigenous people in the village framework. In the first type, indigenous peoples make it possible to effectively strengthen village 
institutions and produce village policies that guarantee customary rights in the village. Whereas, in the second type, it is necessary to encourage democratic dialogue between communities to build a shared understanding of the social barriers that will be solved by ensuring the quality of participation of minority indigenous groups in the policymaking process.

The above strategy is in line with the mandate of the Village Law, which is to guarantee the birth of social inclusion at the village level, both in terms of Village Arrangement, Village Governance, Village Development and Village Regulation Making. In each of these aspects, the Village Law requires administrators of village government to work with democratic principles, gender justice and non-discrimination, and include marginal groups (minority groups) in decision making (deliberation) and supervision (Zakaria, Yando \& Simarmata, 2015).

That is, normatively, the Village Law provides an opportunity to form village institutions in accordance with local aspirations (adat) to strengthen rights and also guarantee a democratic, participatory process including aspirations for the implementation of customary principles and social inclusion in the administration of village and village development. If linked in the context of the village type above, then in the type of village is homogeneous, the Village Law provides an opportunity for the recognition of indigenous peoples in the form of traditional villages. The traditional village envisaged by the Village Law is in line with the principle of participation and democracy based on adat. In this context, adat is expected to be able to balance the implementation processes of government, builders and formulation of policies at the village level.

An inclusive village is a village that grows into a public institution that is oriented towards the interests of citizens. The emergence of this inclusive village gained outside influences such as civil society organizations. Various outside institutions continue to respect local wisdom, but they begin to introduce participatory planning that brings village leaders and communities to divert discussions from communal and parochial issues into public issues such as service, planning and finance. Their presence brings new values such as transparency, accountability, participation, multiculturalism, and gender equality which slowly undergoes organic internalization and institutionalization in village government, planning and financial management. Therefore, inclusive villages grow into public institutions that are able to transcend customary, communal and parochial institutions, and even be able to penetrate corporate character. Although kinship (parochial) persists in inclusive villages, the influence of kinship weakens in the administration and development. The BPD carries out a check and balances function towards the village head but the spirit of BPD's partnership with the village government is well maintained. The PKK is no longer a corporatist institution but has grown to become a political representation base for rural women, where women leaders fight for the rights and interests of children and women.

\section{Village Social Inclusion}

The definition of social inclusion is the opposite of the definition of social exclusion. According to defines social exclusion as a process that makes certain individuals or groups unable to participate partially or fully, in their social life. So according to, Social Inclusion is a process that allows certain individuals or groups to be able to participate partially or completely in their social life. Social inclusion refers to the definition put forward by the World Bank, is a process to increase the requirements for individuals and groups to participate in society.

Social inclusion is intended to empower the poor and marginalized to take advantage 
of global development opportunities. This approach ensures everyone has equal opportunities in decision making that affect their lives and that they enjoy equal access to market systems and services and political space, both socially and physically. The World Bank (2005), even stated that Social Inclusion is the main principle to end extreme world poverty in 2030 and promote prosperity together. Social inclusion is an effort to place the dignity and independence of individuals as the main capital to achieve an ideal quality of life.

The social inclusion approach encourages all elements of society to get equal treatment and get equal opportunities as citizens, regardless of differences in religion, ethnicity, physical condition, sexual orientation choices and others. Social inclusion embraces all citizens who experience stigma and marginalization, by inviting the wider community to act inclusive in everyday life. Simply put, social inclusion as an effort to encourage people to build social relations and solidarity, so that they can open access and acceptance to all citizens without exception, and do voluntary methods without coercion. So social inclusion requires understanding not to isolate and isolate each other and begin to accept differences as a human right. Opening the door means inviting "people who are excluded" to build new relationships and realize their formal rights. While the excluded group is willing to build new relationships and realize their formal rights. This process may interfere at the beginning, but contributes to social stability, longterm cohesion and solidarity. Efforts to achieve sustainable, equitable and pro-marginalized development require inclusive community participation. This process can be done by using or adapting existing social institutions such as open meetings or collective community activities (such as farming) to encourage information exchange. Another step is to ensure that there are open mechanisms or forums for the community to express disagreement with existing activities, programs or policies (Ndraha, 1997). This open forum also allows a feedback process, where the planning and implementation of development programs are adapted and directed together with the community.

Inclusion in development is a concept that needs to be translated by the community in which the process takes place. This is a continuous learning process in which the learning space is the community itself, and the learning instrument is the institution (rules, practices, traditions and culture) that is available and open to be used, adapted, or re-created by the community concerned. That way, then development brings social change and empowerment. The Social Inclusion Approach aims to ensure universal fulfillment of human rights, service of basic needs (able to access, basic services), full social participation (against isolation), and recognition of identity and respect in a unified whole. Inclusion is used as an approach to building and developing an increasingly open environment, inviting entry and involving all people with different backgrounds, characteristics, abilities, status, conditions, ethnicity, culture and others.

Referring to Chapter I of Article 3 of the Village Law, explains that Village Arrangements are based on recognition, subsidiarity, diversity, togetherness, mutual cooperation, kinship, deliberation, democracy, independence, participation, equality, empowerment, and sustainability. From the principle of regulation, there are principles and meanings that the Village is encouraged to make an open, friendly, obstructing society and fun. Because every citizen without exception respects each other and embraces every difference. All of these are characteristics or models as well as capital for building the Inclusion Village. Meanwhile, if referring to Article 4 of the Village Law concerning Village Arrangement, especially on Points c, d, e, f, g, h and i, it clearly encourages the Village to practice and apply the values of Social Inclusion. In point $C$ it reads "Preserving and promoting the customs, traditions and 
culture of the village community". Point D reads "Encouraging village initiatives, movements and participation for the development of village potential and assets for mutual welfare". Poin E reads "Forming a Village Government that is professional, efficient and effective, open and responsible. Point F reads "Improving public services for villagers to accelerate the realization of public welfare. Poin G reads "Increasing the social and cultural resilience of the village people to realize the village community that is able to maintain social unity as part of national security".

Poin H reads "Promoting the economy of the village community and overcoming the national development gap". While Point I reads "Strengthening Village communities as the subject of development". In the Explanation section of Law Number 6 of 2014 concerning Villages, hereinafter referred to as the Village Law, among other things stated that "the implementation of the Village regulations that have been in force is no longer in line with the times, especially among other things concerning the position of indigenous peoples, democratization, diversity, community participation, as well as progress and even distribution of development that creates disparities between regions, poverty, and sociocultural problems that can disrupt the integrity of the Unitary Republic of Indonesia."

Thus, the Village Law can be said to use a social inclusion perspective. There are three forms of social inclusion in the Village Law. The division into 3 forms is based on the target of the marginal group. The first form is the recognition of customary law communities to organize a government based on the rights of origin and original arrangement (subsidiarity). This recognition provides an opportunity for customary law communities to participate in the development and administration of government in general. The second form, social inclusion in the Village Law in the form of providing opportunities for poor groups and women to participate in village planning and implementation, as well as village development (Daljoeni, 1998). As for the third form, social inclusion is addressed to all villagers, including marginalized groups, to participate in village planning, village planning, governance and village development.

Village Social Inclusion intends the Village to develop with a system of openness, all elements of society with different backgrounds, characteristics, abilities, status, conditions, ethnicity, culture and others are actively involved in the implementation of development in the Village including enjoying the results of development in the Village. The principle of social inclusion in the development of the village becomes important so that equality of opportunity and rights of all elements of the community together with the village government take part in the development process in the village, there is no element in the village community that experiences injustice and discrimination in the development process.

Although there is a presence of marginal people in village meetings, their presence is more to fulfill the attendance list only. The village government claimed to have given them the opportunity to speak in a discussion forum, but the opportunity was not utilized. In the case of women's involvement, usually women's groups present at village meetings represent PKK institutions or religious associations. Nevertheless the quality of their involvement is still considered insufficient in the deliberation process and women's representatives are limited to village elites and are not actively speaking. In other places, even though there are regular meetings between women and men, the aspiration shelter is generally represented by male family heads. The level of community participation tends to be higher if meetings and activities are held below the village level, namely in the hamlet, RW or RT. This is because apart from being caused by access, the forums are generally considered more 
familiar and familiar. This means that if activities are held at the village level, citizen participation will shrink. The same thing also happens for development activities where community involvement will be higher if the construction site is located in a location around their residence. In the preparation of the RPJMDes and RKPDes documents, most villages that have been reviewed by SMERU (Sentinel Village 2016) have carried out a series of deliberations arranged in Permendagri No. 66/2007 concerning Village Development Planning. However, meetings at the RT level were only used to explore proposals as input for the preparation of the RPJMDes.

Whereas in the RKPDes process, the process of determining development priorities to take place elitist by involving several people as the drafting team and not involving the community. Similar things were also found in the drafting of the APBDes which were usually carried out by village officials, including the Village Head, the Head of Development, the Village Treasurer, the District Secretary and the General Head. Often the budgeting process involves only a handful of people who are considered by the village government to be cooperative. Although this does not violate the rules because the Minister of Home Affairs Regulation No. 113/2015 only requires that discussions be carried out between the village government and the BPD, not participating in the community, the potential for abuse of authority. In general, the village government has not facilitated a more participatory process and approach. This priority-setting process has resulted in delays or non-implementation of development activities which according to the community are considered very needed.

\section{Conclusion}

Social inclusion is one of the goals in the Village Law to end extreme poverty conditions in villages. Encouraging villages to design the Village of Inclusion is an effort to realize the prosperity of the village together. Social inclusion is a result as well as a process to encourage the level of involvement of villagers in community life. The Village Law No. 6/2014 explicitly seeks to transform villages into inclusive villages. An inclusive village means giving equal opportunities to all citizens to gain access, participation, control and development benefits. Increasing welfare through rural economic development is one of the spirit that is carried by the Village Law. The opportunity to implement participatory planning and budgeting that is pro poor and gender responsive and friendly to the marginalized is more open with the introduction of two approaches in the Village Law. The approach is "Building Villages" and "Building Villages" which are integrated in Village planning. Law No. 6/ 2014 also mandated that village officials carry out participatory development. Participatory development is a system of development management in villages and rural areas that is coordinated by the village head.

In the development process must prioritize togetherness, kinship and mutual cooperation. The aim is to realize mainstreaming of peace and social justice. In order to achieve this goal, there is a need to ensure that there is an open space for participation for the community at every stage and village planning process carried out by the village as is done by the Village Law. Article 23 Village Law No. 2/2014 has guaranteed access openness to participate in the Village Conference to all villagers. This means that both men and women, both from the community and the poor have the same rights to participate.

\section{References}

Alim, M. (2001). Demokrasi dan Hak Asasi Manusia dalam Konstitusi Madinah dan UUD 1945. Yogyakarta: UII Pres.

Arikunto, S. (2010). Prosedur penelitian suatu pendekatan praktik. Jakarta: PT Rineka Cipta.

Bachtiar. (2011). Analisis faktor-faktor yang mempengaruhi kepuasan mahasiswa 
dalam memilih Politeknik Sawunggalih Aji Purworejo. Dinamika Sosial Ekonomi, 7(1), 102-112.

Deni, J. A. (2006). Catatan Politik. Yogyakarta: LKIS Yogyakarta.

Daldjoeni. (1998). Geografi Kota dan Desa. Bandung: PT Alumni.

Dryzek, J. S. (1996). Political inclusion and the dynamics of democratization. American Political Science Review, 90(1), 475-487.

Eamage, E. D. (2002). Percaturan politik di Indonesia: Demokrasi, islam dan ideologi toleransi. Jogjakarta: Mata Bangsa.

Effendi, B. (2001). Teologi baru agama Islam: Pertautan agama, negara dan demokrasi. Yogyakarta: Galang Printika.

Firmansyah. (2008). Mengelola partai politik: Komunikasi dan positioning ideologi politik di era demokrasi. Jakarta: Yayasan Obor Indonesia.

Gede, I. D. (2011). Konsepsi Demokrasi dalam Bingkai Konstitusi. Malang: Setara Press.
Henley, D., \& Davidson, J. (2010). Pendahuluan: Konservatisme radikal-aneka wajah politik adat. In J. S. Davidson, D. Henley, \& S. Moniaga (Eds.), Adat dalam politik Indonesia. Jakarta: Yayasan Pustaka Obor Indonesia.

Ndraha, T. (1997). Budaya Organisasi. Jakarta: Rineka Cipta.

Permendagri No. 66/2007 concerning Village Development Planning

Sugiyono. (2007). Metodologi Penelitian Bisnis. Jakarta: PT. Gramedia.

Sugiyono. (2009). Metode penelitian kuantitatif, kualitatif dan RED D. Bandung: Alfabeta.

The World Bank. (2005). Poverty reduction and economic Management network. Washington: Poverty Reduction Group.

Usman, H. (2008). Metodologi penelitian sosial. Jakarta: Bumi Aksara.

Zakaria, R., Yando, Z., \& Simarmata, R. (2015). Mempromosikan program inklusi sosial dan pembangunan yang inklusif melalui upaya optimalisasi Undang-Undang No. 6 Tahun 2014 tentang Desa (Rep.) 